\title{
Assessment of anaemia in pregnant women attending antenatal Care in medical facilities within Ekwulobia, Aguata local government area, Anambra state Nigeria
}

\author{
Oguizu AD*, Orjiekwe OA
}

Department of Human Nutrition and Dietetics, Michael Okpara University of Agriculture, Umudike, P.M.B. 7267, Umuahia, Abia State, Nigeria

\begin{abstract}
Introduction: Anaemia is one of the public health problems in developing countries. It is an indirect cause of maternal morbidity and mortality.

Objective: The study was carried out to determine the prevalence of anaemia among pregnant women attending antenatal care in Medical Facilities within Ekwulobia, Aguata Local Government Area, Anambra State.

Methods: Two hundred and two pregnant women were purposively selected for the survey. The pregnant women were selected from General hospital, Cynic specialist hospital, Primary Health Centre and St. Victoria specialist hospital all in Ekwulobia. The instruments used for data collection were questionnaire and biochemical analysis. Data were collected on background information, personal data, socio-economic and environmental factors. Blood samples were collected from the antecubital vein to determine the Hemoglobin concentration of the respondents using automated analyzer.

Results: The finding revealed that $36.2 \%$ women were anaemic. About $33.7 \%$ were mildly anaemic while $2.5 \%$ were moderately anaemic. The result revealed $43.3 \%, 34.8 \%$ and $28.8 \%$ of pregnant women in their 1st, 2nd, and 3rd trimester respectively had their hemoglobin concentration less than $11 \mathrm{~g} / \mathrm{dl}$ (mild anaemia). About $3.3 \%$ and $2.5 \%$ of pregnant women in their 2 nd and 3rd trimesters respectively had moderate anaemia (less than $9 \mathrm{~g} / \mathrm{dl}$ ). There was a relationship $(p<0.05)$ between the women's haemoglobin concentration and education $(p=0.008)$, occupation ( $p=0.027)$ and birth spacing $(p=0.036)$.
\end{abstract}

Conclusion: The prevalence of anaemia in the pregnant women was high indicating a public health problem.

Keywords: Anaemia, Pregnant women, Prevalence, Aguata L.G.A, Anambra state, Nigeria

Accepted on November 29, 2018

\section{Introduction}

Anaemia is defined as a reduction in the red cell mass in the blood resulting in a drop in oxygen supply to meet the metabolic needs of the body [1]. Anaemia in pregnancy continues to be a global problem associated with increased maternal morbidity and mortality particularly in developing countries such as Nigeria [2]. It is a disorder of great public health importance in poor countries especially in Sub-Saharan Africa. Pregnant women and young children especially preschool age group are the most vulnerable [3]. Anaemia affects over half of the pregnant women in developing countries [4]. Estimates in developing countries including Nigeria put the prevalence at $60.0 \%$ in pregnant woman and about $7.0 \%$ are said to be severely anaemia [5]. Some $20 \%$ of maternal death in Africa and $11 \%$ in Nigeria have been attributed to anemia [6]. Anaemia has social and demographic implications [7]. Anaemia in pregnancy is a very common medical disorder, with significant implications for both mother and child [8]. Its primary cause is iron deficiency, but also occurs due to other causes like parasitic infection, malaria in endemic tropical countries of Africa, nutritional deficiencies and hemoglobinopathies and recently human immunodeficiency virus infection [3,9]. There is a high level of ignorance and cultural beliefs about anemia in pregnancy, as well as its prevention and treatment in our environment [10]. Pregnancy age, grandmultiparity, low socioeconomic class and poor maternal education are some of the factors associated with maternal anaemia in some Nigerian studies [11,12]. An important factor that is common in the tropics but is often overlooked is socio-economic deprivation. This has been linked with the development, severity and outcome of many medical conditions [7]. Poverty and low standards of living are still major problems facing most developing countries. Regardless of the huge deposits of mineral resources, Nigeria still ranks the 13 th poorest country in the world with about $72 \%$ of the country's population living below the poverty line (World Bank, 2006). The ability of women to command resources and make independent decisions about their fertility, their health and health care also has an impact on maternal anaemia. Appropriate prenatal interventions like iron supplementation helps in reducing the prevalence [13]. 
Citation: Oguizu AD, Orjiekwe OA. Assessment of anaemia in pregnant women attending antenatal Care in medical facilities within Ekwulobia, Aguata local government area, Anambra state Nigeria. J Food Sci Nutr. 2018;1(3):26-31.

\section{Specific objectives}

(i) Assess the prevalence of anaemia among pregnant women.

(ii) Identify the factors that could predispose the pregnant women to anaemia.

(iii) Assess the relationship between anaemia and the socioeconomic variables observed in the women.

\section{Materials and Methods}

\section{Study design}

A cross-sectional survey was used for this study.

\section{Area of study}

The study was conducted in Ekwulobia, in Aguata Local Government Area, Anambra State. Ekwulobia is the headquarter of Aguata L.G.A. The town is located within latitude $6.33^{\circ} \mathrm{N}$ and longitude $7.08^{\circ} \mathrm{E}$. Ekwulobia has a population of 500,000 people [14]. The inhabitants are predominantly farmers, traders, civil servants, students, merchants, who are typically Igbos, and few inhabitants from other tribes like Yoruba, Hausa, and Cross River. Ekwulobia town is made up of nine villages; Okpo, Ula, Umuchiana, Umuchi, Ihuokpala, Eziagulu, Agba, Abogwume and Nkonu.

\section{Population of the study}

The study population comprised of pregnant women attending antenatal care in Ekwulobia.

\section{Sampling and sampling techniques}

The sample size $(\mathrm{N})$ was determined by the equation below:

The sample size $(\mathrm{N})=\frac{\mathrm{Z}^{2} \times \mathrm{P}(100-\mathrm{P})}{\mathrm{X}^{2}}$

$\mathrm{Z}=$ an acceptable margin of error of 1.96 at $95 \%$ confidence interval would be used and approximated to 2 .

$\mathrm{P}=$ Percentage of maternal mortality in pregnancy as a result of anaemia in Nigeria is $11 \%$ (United Nation Population Fund, 2015).

$100-\mathrm{P}=$ Percentage of pregnant woman that did not die as a result of anaemia.

$\mathrm{X}=$ width of confidence interval or required precision level taken to be $5 \%$

$=4 \times 39.16=154.64=4 \times 39.16=154.64$.

The sample size was increased to two hundred and two to make up for attrition.

\section{Sampling procedure}

There are eight hospitals and one primary health centre in Ekwulobia. From the nine Facilities, four medical facilities were selected using simple random sampling method by balloting. The selected medical facilities included General hospital Ekwulobia, Cynvic specialist hospital and maternity, Primary Health Centre Ekwulobia and St. Victoria specialist hospital and maternity. The pregnant women registered in the four medical facilities were selected using purposive sampling technique.

\section{Preliminary Activities}

\section{Preliminary visit}

Prior to the survey, a preliminary visit was made to the medical facilities to inform them on the importance of the survey. Permission was also sought to allow the researchers carry out data collection

\section{Training of research assistant}

Three research assistants were trained to assist the researcher on data collection. The purpose and objectives of the study were communicated and clearly explained to them.

\section{Ethical approval}

Ethical approval was obtained from the Ethical Committee of the Medical Facilities before the study commenced. The respondents were requested to fill informed consent forms, for their approval of blood collection for the research.

\section{Data Collection}

\section{Questionnaire administration}

A validated and pretested questionnaire was used to collect information on background information, personal data, socioeconomic status and environmental factors.

\section{Background information}

Age, religion, marital status, number of pregnancies and number of children.

\section{Socio-economic status and environmental factors}

These include educational level, occupation, monthly income, type of family and number of people in the household, foods forbidden in the area for pregnant women.

\section{Collection of blood samples}

From each of the recruited women, 5 milliliters of venous blood was collected from the antecubital vein, using plastic disposable syringes into plastic bottles containing ethylene di-amine-tetra acetic acid (EDTA).

\section{Biochemical assessment}

Two capillary tubes labeled for each subject were filled with blood for about $2 / 3$ of the length of each tube. This was to ensure that an average of the two values obtained was used for calculation. Several labeled samples were assembled in the centrifuge (haematocrit machine). Haemoglobin concentrations were determined using automated analyzer. Haemoglobin less than $11.0 \mathrm{~g} / \mathrm{dl}$ during pregnancy was regarded as anaemia by World Health Organization [7].

\section{Data and Statistical Analysis}

Haemoglobin concentration below $11.0 \mathrm{~g} / \mathrm{dl}$ during pregnancy was regarded as anaemia. Data were analyzed using Statistical Package for Social Sciences (SPSS version 20.0). Statistical data was expressed as frequency and percentages. Pearson's correlation between the variables was computed and Chi square was also used to determine the significance between the variables. 


\section{Results}

\section{Background information of the pregnant women}

Table 1 shows the background information of respondents. About $27.7 \%$ of the women were between $20-24$ years, $33.2 \%$ were between $25-29$ years and $23.3 \%$ were $30-34$ years. Only a few $(1.5 \%)$ were above 40 years. Majority of the women (92.1\%) were married. All the women were Christians (100\%). Most of the women (94.1\%) were Igbo.

\section{Personal data of the pregnant women}

Table 2 shows the personal information of the pregnant women. About $45.5 \%$ of the women were in their second trimester

Table 1. Background information of the pregnant women.

\begin{tabular}{|c|c|c|}
\hline Variables & Frequency & Percentage \\
\hline \multicolumn{3}{|c|}{ Age (years) } \\
\hline $15-19$ & 7 & 3.5 \\
\hline $20-24$ & 56 & 27.7 \\
\hline $25-29$ & 67 & 33.2 \\
\hline $30-34$ & 47 & 23.3 \\
\hline $35-40$ & 22 & 10.9 \\
\hline Above 40 & 3 & 1.5 \\
\hline Total & 202 & 100 \\
\hline \multicolumn{3}{|c|}{ Marital status } \\
\hline Married & 186 & 92.1 \\
\hline Single & 11 & 5.4 \\
\hline Divorced & 1 & 0.5 \\
\hline Widowed & 2 & 1.0 \\
\hline Others & 2 & 1.0 \\
\hline Total & 202 & 100 \\
\hline \multicolumn{3}{|l|}{ Religion } \\
\hline Christian & 202 & 100 \\
\hline \multicolumn{3}{|c|}{ Ethnic group } \\
\hline Yoruba & 0 & 0 \\
\hline Hausa & 1 & 0.5 \\
\hline Igbo & 190 & 94.1 \\
\hline Others & 11 & 5.4 \\
\hline Total & 202 & 100 \\
\hline
\end{tabular}

Table 2. Personal data of the pregnant women.

\begin{tabular}{|c|c|c|}
\hline Variables & Frequency & Percentage \\
\hline \multicolumn{3}{|l|}{ Stage of pregnancy } \\
\hline 1-3 months (1st trimester) & 30 & 14.9 \\
\hline 4-6 months (2nd trimester) & 92 & 45.5 \\
\hline 7-9 months (3rd trimester) & 80 & 39.6 \\
\hline Total & 202 & 100 \\
\hline \multicolumn{3}{|l|}{ Number of pregnancy } \\
\hline Two & 51 & 25.2 \\
\hline Three & 37 & 18.3 \\
\hline Four & 12 & 5.9 \\
\hline Five and above & 21 & 10.4 \\
\hline First pregnancy & 81 & 40.1 \\
\hline Total & 202 & 100 \\
\hline \multicolumn{3}{|l|}{ Had miscarriage } \\
\hline Yes & 30 & 14.9 \\
\hline No & 172 & 85.1 \\
\hline Total & 202 & 100 \\
\hline \multicolumn{3}{|l|}{ Number of children } \\
\hline 01-Feb & 77 & 38.1 \\
\hline 03-Apr & 27 & 13.4 \\
\hline 05-Jun & 17 & 8.4 \\
\hline None & 81 & 40.1 \\
\hline Total & 202 & 100 \\
\hline
\end{tabular}

while $39.6 \%$ were in their third trimester. Only $14.9 \%$ were in their first trimester. More than half $(59.9 \%)$ of the women were multigravida, while $40.1 \%$ were primigravida. For the multigravida, $14.9 \%$ of them have had miscarriage. About $38.1 \%$ of the pregnant women had one to two children, $13.4 \%$ had three to four children. Only a few $(8.4 \%)$ had five to six children

\section{Socio-economic status of the pregnant women}

Table 3 shows the socio-economic status of the pregnant women. More than half of the women (54.5\%) completed their secondary education, $28.2 \%$ completed their tertiary education. Only $4 \%$ had no formal education. About $23.3 \%$ of the pregnant women were traders, $22.3 \%$ were business women, while $16.3 \%$ were civil servants. About $48 \%$ of the women earned 5,000-10,000 naira per month, $24.8 \%$ earned less than 5,000 naira per month. Only a few women (2.0\%) earned 70,000 naira and above.

\section{Foods forbidden during pregnancy in the study area}

Table 4 shows various foods forbidden in the study area. About $54.0 \%$ of the pregnant women claimed some foods were

Table 3. Socio-economic status of the pregnant women.

\begin{tabular}{|c|c|c|}
\hline Variables & Frequency & Percentage \\
\hline \multicolumn{3}{|l|}{ Level of education } \\
\hline None & 1 & 4.0 \\
\hline Primary School & 20 & 9.9 \\
\hline Secondary School & 110 & 54.5 \\
\hline Tertiary School & 57 & 28.2 \\
\hline others & 7 & 3.5 \\
\hline Total & 202 & 100 \\
\hline \multicolumn{3}{|l|}{ Occupation } \\
\hline Students & 28 & 13.9 \\
\hline Civil servant & 33 & 16.3 \\
\hline Teaching & 44 & 21.8 \\
\hline Trading & 47 & 23.3 \\
\hline Business & 45 & 22.3 \\
\hline Not Employed & 4 & 2.0 \\
\hline other & 1 & 0.5 \\
\hline Total & 202 & 100 \\
\hline \multicolumn{3}{|l|}{ Monthly income } \\
\hline Less than $\$ 5000$ & 50 & 24.8 \\
\hline A5000-A10000 & 97 & 48.0 \\
\hline N10000- $\$ 30000$ & 30 & 14.9 \\
\hline \#30000- $\$ 69000$ & 21 & 10.4 \\
\hline N70000 and above & 4 & 2.0 \\
\hline Total & 202 & 100 \\
\hline
\end{tabular}

Table 4. Foods forbidden during pregnancy in the study area.

\begin{tabular}{|l|c|c|}
\hline Variable & Frequency & Percentage \\
\hline Foods forbidden & & \\
\hline Egg & 14 & 6.9 \\
\hline Liver & 12 & 5.9 \\
\hline Kidney & 14 & 6.9 \\
\hline Red meat & 9 & 4.5 \\
\hline Dark green vegetable & 9 & 4.5 \\
\hline Cray fish & 7 & 3.5 \\
\hline Periwinkle & 15 & 7.4 \\
\hline Mackerel & 9 & 4.5 \\
\hline Cowpea & 7 & 3.5 \\
\hline Snail & 13 & 6.4 \\
\hline None & 93 & 46.0 \\
\hline Total & $\mathbf{2 0 2}$ & $\mathbf{1 0 0}$ \\
\hline
\end{tabular}


Citation: Oguizu AD, Orjiekwe OA. Assessment of anaemia in pregnant women attending antenatal Care in medical facilities within Ekwulobia, Aguata local government area, Anambra state Nigeria. J Food Sci Nutr. 2018;1(3):26-31.

forbidden in their area during pregnancy egg was forbidden by $6.9 \%$ of the respondents, liver $5.9 \%$, kidney $6.9 \%$, red meat $4.5 \%$, dark green vegetable $4.5 \%$, crayfish $3.5 \%$, periwinkle $7.4 \%$, mackerel $4.5 \%$, cowpea $3.5 \%$ and snail by $6.4 \%$ of respondents.

\section{Prevalence of anaemia among pregnant women}

Table 5 shows the prevalence of anaemia among the pregnant women. About $33.7 \%$ of the women had moderate anaemia while $2.5 \%$ had mild anaemia. None of the women had severe anaemia.

\section{Prevalence of anaemia among pregnant women by trimesters}

Table 6 shows the prevalence of anaemia among the pregnant women according to their different trimesters. About $43.3 \%$ of

Table 5. Prevalence of anaemia among pregnant women.

\begin{tabular}{|l|c|c|}
\hline Biochemical assessment & Frequency & Percentage \\
\hline Haemoglobin & & \\
\hline $13-14.99$ (High normal) & 12 & 5.9 \\
\hline $11-12.99$ (normal) & 117 & 57.9 \\
\hline 9-10.99 (mild anaemia) & 68 & 33.7 \\
\hline $7-8.99$ (moderate anaemia) & 5 & 2.5 \\
\hline$<7$ (Severe) & 0 & 0 \\
\hline Total & $\mathbf{2 0 2}$ & $\mathbf{1 0 0}$ \\
\hline
\end{tabular}

women in their first trimester had mild anaemia. None of the women in their first trimester had moderate or severe anaemia. For women in their second trimester, $34.8 \%$ had mild anaemia, $3.3 \%$ had moderate anaemia. For women in their third trimester, $28.8 \%$ had mild anaemia while $2.5 \%$ had moderate anaemia. There was no significant relationship $(p>0.05)$ between pregnancy age and anaemia.

\section{Relationship between anaemia and socioeconomic variables}

Table 7 shows the relationship between hemoglobin concentration and socioeconomic characteristics of the women. From the result, there was a significant relationship $\left(x^{2}=20.206\right.$; $\mathrm{p}=0.008$ ) between education and hemoglobin concentration. There was also a significant relationship between occupation and haemoglobin level $\left(x^{2}=20.846 ; p=0.027\right)$ of the women.

\section{Discussion}

Most of the respondents were between 20-34 years. Only a few $(3.5 \%)$ were $15-19$ years. This shows that adolescence and early pregnancy is in decline [15]. Majority of the women (92.1\%) were married, this could be as a result of religions practices in the area that does not encourage child birth out of wedlock [15]. All the women were Christians (100\%) this is not strange because almost all the respondents were from Igbo tribe and Christianity is the main religion practiced in South

Table 6. Prevalence of anaemia among pregnant women by trimesters.

\begin{tabular}{|c|c|c|c|c|c|}
\hline Indicator & $\begin{array}{c}1-3 \text { months } \\
\text { (1st trimester) NO\% }\end{array}$ & $\begin{array}{c}\text { 4-6 months } \\
\text { (2nd trimester) NO\% }\end{array}$ & $\begin{array}{c}\text { 7-9 months } \\
\text { (3rd trimester) NO\% }\end{array}$ & $\begin{array}{c}\text { Total prevalence } \\
\text { NO\% }\end{array}$ & p-value \\
\hline \multicolumn{6}{|l|}{ Haemoglobin (g/dl) } \\
\hline High normal (13-14.99) & $2(6.7)$ & $4(4.3)$ & $6(7.5)$ & $12(5.9)$ & 0.725 \\
\hline Normal (11-12.99) & $15(50.0)$ & $53(57.6)$ & $49(61.2)$ & $117(57.9)$ & \\
\hline Mild (9-10.99) & $13(43.3)$ & $32(34.8)$ & $23(28.8)$ & $68(33.7)$ & \\
\hline Moderate (7.00-8.99) & $0(0.0)$ & $3(3.3)$ & $2(2.5)$ & $5(2.5)$ & \\
\hline Severe anaemia $(<7)$ & $0(0.0)$ & $0(0.0)$ & $0(0.0)$ & $0(0.0)$ & \\
\hline Total & $30(100)$ & $92(100)$ & $80(100)$ & $202(100)$ & \\
\hline
\end{tabular}

Table 7. Relationship between anaemia and socioeconomic variables.

\begin{tabular}{|c|c|c|c|c|c|c|c|c|c|}
\hline Variables & $\begin{array}{l}\text { Normal } \\
\text { NO }\end{array}$ & $\%$ & Anaemia Mild NO & $\%$ & Moderate NO & $\%$ & Total NO & $\%$ & P-value \\
\hline \multicolumn{10}{|l|}{ Education } \\
\hline None & 3 & 2.6 & 3 & 4.4 & 0 & 0.0 & 0.0 & 4.0 & \multirow[t]{6}{*}{0.008} \\
\hline Primary & 12 & 10.3 & 5 & 7.4 & 2 & 0.0 & 0.0 & 9.9 & \\
\hline Secondary & 63 & 53. & 37 & 54.4 & 2 & 16.7 & 107 & 53.0 & \\
\hline Tertiary & 34 & 29. & 18 & 26.5 & 0 & 0.0 & 55 & 27.2 & \\
\hline Others & 2 & 1.7 & 5 & 7.4 & 1 & 20.0 & 12 & 6.0 & \\
\hline Total & 117 & 100 & 68 & 100 & 5 & 100 & 202 & 100 & \\
\hline \multicolumn{10}{|l|}{ Occupation } \\
\hline Students & 19 & 16. & 9 & 13. & 0 & 0.0 & 28 & 13.9 & \multirow{7}{*}{0.027} \\
\hline Civil servant & 26 & 22. & 4 & 5.9 & 0 & 00 & 33 & 16.3 & \\
\hline Teaching & 24 & 20. & 15 & 22. & 1 & 20.0 & 44 & 21.8 & \\
\hline Trading & 26 & 22. & 17 & 25. & 2 & 40.0 & 47 & 23.3 & \\
\hline Business & 21 & 17. & 19 & 27. & 2 & 40.0 & 45 & 22.3 & \\
\hline Not Employed & 1 & 0.9 & 3 & 4.4 & 0 & 0.0 & 4 & 2.0 & \\
\hline Others & 0 & 0.0 & 1 & 1.5 & 0 & 0.0 & 1 & 0.5 & \\
\hline Total Income & 117 & 100 & 68 & 100 & 5 & 100 & 202 & 100 & \multirow{6}{*}{0.319} \\
\hline$<N 5000$ & 27 & 23.1 & 18 & 26.7 & 1 & 20.0 & 50 & 24.8 & \\
\hline A5000-N10000 & 52 & 44.4 & 34 & 50.0 & 4 & 80.0 & 97 & 48.0 & \\
\hline N10000-N30000 & 21 & 17.9 & 9 & 13.2 & 0 & 0 & 30 & 14.9 & \\
\hline N30000-N69000 & 13 & 11.1 & 7 & 10.3 & 0 & 0.0 & 21 & 10.4 & \\
\hline A70000 and above & 4 & 3.4 & 0 & 0.0 & 0 & 0.0 & 4 & 2.0 & \\
\hline Total & 117 & 100 & 68 & 100 & 5 & 100 & 202 & 100 & \\
\hline
\end{tabular}


East [15]. Majority of the women were in their second (45.5\%) and third (39.6\%) trimesters. It has been observed that women do not start attending antenatal care immediately they become pregnant, some would continue to wait until they fall sick before they register for antenatal [6]. More than half (59.9\%) of the pregnant women were multigravida. This could be attributed to lack of family planning method. In Nigeria, some cultures and traditions prohibit women from accepting and practicing family planning, thus giving rise to multiparity and inter pregnancy, hence causing large family size, depleting maternal iron store and consequent nutrition inadequacy [16]. More than half of the women $(54.5 \%)$ had completed only secondary education. The low income earnings observed in the respondents maybe as a result of the low educational status of the women in the study area. This result is similar to the study of Idowu et al. (2005) where it was observed that the monthly income of pregnant women was low [6]. More than half of the respondents $(54.0 \%)$ claimed some foods were forbidden in their places during pregnancy. These foods were forbidden as a result of traditional and superstitious believe. Inadequate consumption of foods could predispose them to nutritional deficiencies especially anaemia. Diverse cultural practices restricting the consumption of foods high in iron could affect the haemoglobin level of women during pregnancy. The finding revealed that $36.2 \%$ women were anaemic. This result is closely related to the research of Ikeanyi and Ibrahim (2015) that reported the prevalence of anaemia to be $32.2 \%$ [17]. This result is lower when compared with the research conducted by Idowu et al. (2005) they reported the prevalence of anaemia among pregnant women in their study to be $76.5 \%$ [17]. This prevalence of anaemia observed in in the study area may be related to short birth spacing, low educational level and occupations of pregnant women in the study area. Anaemia was observed at the different trimesters of pregnancy and this could be as a result of inadequate intake of foods rich in iron leading to a reduction in the iron stores of the women. In pregnancy, there is plasma volume expansion which begins to increase during the first week of conception, and continue to expand at a relatively rapid rate, causing dilution of the red blood cells (haemodilution). Pregnancy increases the demand for folic acid, and therefore poses the risk of iron deficiency anaemia. There was a significant relationship $\left(\mathrm{x}^{2}=20.206 ; \mathrm{p}=0.008\right)$ between education and hemoglobin concentration. This shows that the proportion of anaemic women increased with decrease level of education. Lack of education reduces women's access to economic opportunities such as employment, thus affecting her learning capacity and difficulty to afford adequate nutrition. Illiteracy hinders her acceptance and practice of perinatal care advice and knowledge of proper nutrition, as well as methods of food preparation $[3,18]$. There was significant relationship between occupation and their haemoglobin level $\left(x^{2}=20.846\right.$; $\mathrm{p}=0.027)$. Majority of the women were traders and business women, this might have taken much of their time and energy thus depriving the women from eating adequately.

\section{Conclusion}

The prevalence of anaemia in the pregnant women was high indicating a public health problem. Anaemia in pregnancy especially in Nigeria continues to be a public health problem associated with increased maternal morbidity and mortality.
The study also observed that some socio economic factors such as occupation and education affected the haemoglobin concentration of the pregnant women. Diverse cultural practices (food taboos) restricting the consumption of foods high in iron ma have affected the haemoglobin level of women during pregnancy.

\section{References}

1. Lee M, Truma JI. Acute anaemia eMed J. 2007;2(11):45-56.

2. Ndukwu G, Dienye P. Prevalence and Socio-demographic Factors Associated with Anaemia in Pregnancy in a Primary Health Center in Rivers State, Nigeria. Afri J Primary Health Care and Family Med. 2012;4(1):1.

3. World Health Organization (WHO). Worldwide Prevalence of Anaemia, WHO Global Database on Anaemia. World Health Organization, Geneva. Switzerland. 2005;1-40.

4. Omigbodun AO. Recent trends in the Management of Anaemia in pregnancy. Trop J Obstetrics and Gynecology. 2007;21(1):1-3.

5. Agan T, Ekabua JE, Udoh AE, et al. Prevalence of anaemia in women with asymptomatic malaria parasitemia at first antenatal re visit at the University of Teaching Hospital, Nigeria. Int J Women's Health. 2010;2(1):229-33.

6. Idowu OA, Mafiana CF, Sotiloye D. Anaemia in Pregnancy, a Survey of Pregnant Women in Abeokuta, Nigeria. Afri Health J. 2005;5:295-9.

7. Anorlu RI, Oluwole AA, Audu OO. Sociodemographic Factors in Anaemia at booking in Lagos Nigeria. J Obstetrics and Gynaecology. 2006;268:773-76.

8. Milman N. Anaemia: still a major health problem in many parts of the World. Ann Hematol J. 2011;90:369-77.

9. Vanderjagt DJ, Brock HS, Melah GS, et al. Nutritional Factors Associated with Anaemia in Pregnant Women in Northern Nigeria. J Health Popul Nutr. 2007;25(1):75-81

10. Ejidokun OO. Community Attitudes to Pregnancy, Anaemia, Iron and Folate Supplementation in Urban and Rural Lagos, South-Western Nigeria. J Midwifery. 2006;16(7):89-95.

11. Bukar OM, Audu BM, Sadauki HM, et al. Prevalence of iron deficiency and megaloblastic Anaemia at booking in a secondary health facility in North Eastern Nigeria. J Med. 2009;50(2):37-40.

12. Lamina MA, Sorunmu TO. Niger Med Pract J. 2005;47(4):39-42.

13. Milman N. Prepartum Anaemia Prevention and Treatment. J Annals Haematology. 2008;87(4):949-59.

14. World Bank. Human Development Report. Washington DC. 2006.

15. Nnadi R. Prevalence of iron deficiency anaemia among pregnant women in Nsukka Town. B.Sc. Project, Department of Human Nutrition and Dietetics, University of Nigeria, Nsukka. 2005.

16. Population Report. Ending violence against. 1999. 
17. Ikeanyi EM, Ibrahim AI. Does antenatal care prevents anaemia in pregnancy at term. Nig. J Clin Pract. 2015;18(3):323-7.
18. United Nation Population Fund (UNFPA). Prevalence of maternal death in Nigeria. UNFPA report Abuja, Nigeria. 2015;2-15.

\section{${ }^{*}$ Correspondence to:}

Oguizu AD

Department of Human Nutrition and

Dietetics

Michael Okpara University of

Agriculture, Umudike

P.M.B. 7267, Umuahia, Abia State

Nigeria

Tel: +2348038132055

E-mail: ada.ejekwu@gmail.com 